\title{
An Examination Of Kolb's Learning Style Inventory
}

Doreen J. Gooden, Florida International University, USA

Robert C. Preziosi, Nova Southeastern University, USA

F. Barry Barnes, Nova Southeastern University, USA

\begin{abstract}
As educators our primary focus is that of ensuring that students experience positive learning outcomes. Research, however, has shown that there are differences in students' learning styles and that these differences will impact on the overall learning process. One way of ensuring that these positive outcomes are achieved is by identifying the different learning styles of students and modifying our teaching methodology to meeting those needs. This paper examines Kolb's (1984) Learning Style Inventory and provides suggestions on how to address the different students' learning styles in order to enhance the learning process.
\end{abstract}

Keywords: Faculty training, instructional methodologies, Kolb Learning Style Inventory.

\section{INTRODUCTION}

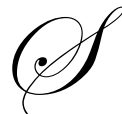

tudies have shown that students' performance is enhanced when learning styles are considered. Kolb (1984) asserts that where learning context and learning styles are matched then this leads to enhanced learning performance. Many colleges and universities in addition to offering ground-based courses are offering online courses. The online delivery of college and university courses is growing and thus, the mandate has to be on consistency of learning outcomes in both ground based and online deliveries.

Barnes et al. (2004) identified differences in the learning styles of the students and that students had preferences in certain course delivery methods over others. In another research paper Barnes et al. (2008) also found that there may be differences in learning outcomes for certain courses when courses are offered at different locations. Tomlinson (1996) emphasizes the need for instructors to be aware of and adapt to student learning styles. Thus, an analysis of students' learning styles can enhance learning and expand the knowledge base of both groundbased and on-line learning.

The purpose of this paper, therefore, is to examine Kolb's Learning Style Inventory and to be able to identify tools that can be used to address the learning styles in the classroom - both ground-based and online.

\section{LITERATURE REVIEW}

Several classifications of learning style and related concepts have been developed through the years. These classifications include Solomon's Inventory of Learning Styles, the Meyers-Briggs Type Indicator, Howard Gardner's multiple intelligences, McCarthy's 4-Mat system, and Honey and Mumford's (1986) social approach to learning. Perhaps the most widely known approach to assessing learning style, however, is that of David Kolb (1984).

Kolb's learning style inventory (1984) is based on two-bipolar dimensions depending on how an individual perceives and internalizes information. Abstract conceptualization and concrete experience describe how information is perceived by individuals while reflective observation and active experimentation examine how individuals process or internalize information. Abstract learners are very analytical and logical, concrete learners learn though examples, reflective learners prefer to observe before making judgments and they tend to be introverts, 
and active learners have experimentation tendencies and they tend to be extraverts. In different learning situations, however, individuals often use different combinations of learning modes; hence no one mode clearly identifies an individual's learning style. The combination of learning modes forms four quadrants reflecting four learning styles: Diverger, Assimilator, Accommodator, and Converger as depicted in Figure 1 below.

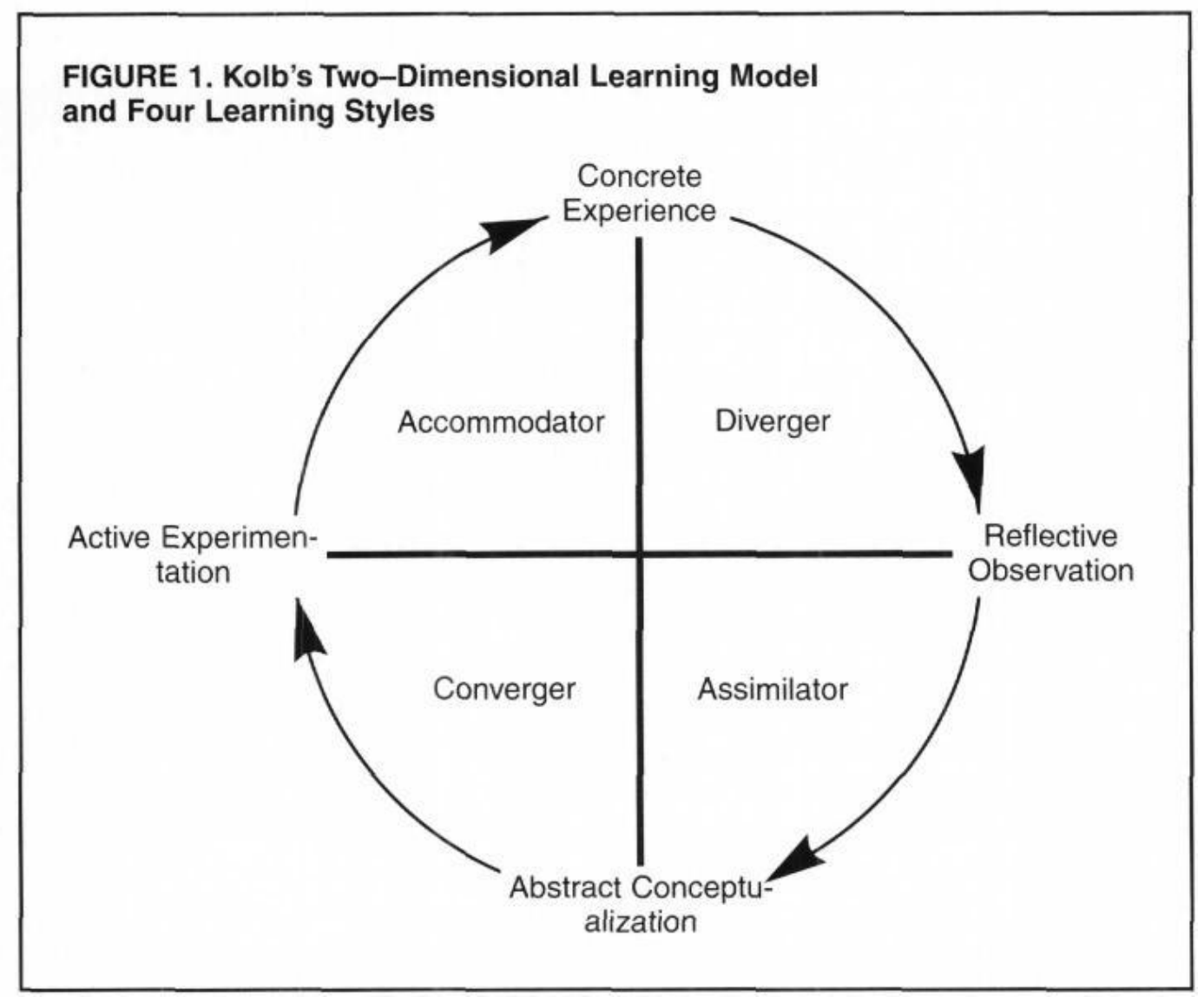

Divergers (combination of concrete experience and reflective observation) - Persons with this learning style like to generate a wide range of ideas and like to gather information. They also have imaginative abilities which enhance creative and view situations from different points of view (Kolb 1984).

Assimilators (combination of abstract conceptualization and reflective observation) - Assimilators are able to understand and formulate information into a logical and concise form. They are more focused on abstract ideas and concepts; hence they are very good at creating models and defining problems. They are also very good planners. (Kolb, 1984)

Convergers (combination of abstract conceptualization and active experimentation) - accommodators learn by understanding concepts and take an active form in learning and are very attentive to detail. (Kolb, 1984)

Accommodators (combination of concrete experience and active experimentation) - Accommodators, like convergers have elements of active experimentation and this takes an active form of learning. Accommodators rely heavily on people for information when solving problems and like to take risks and, thus, will seek out new approaches to complete a project. (Kolb, 1984) 
As indicated above, there is a need to accommodate different learning styles and modes. This accommodation requires more than recognizing the students' learning styles, however. Not only does learning style and mode vary by individual, but teaching style varies as well. Ebeling (2000) suggests that there is evidence most instructors use a teaching style that is comfortable to them and this is often the way they themselves learn best. Tom and Calvert (1984) however, postulate that teachers used the same teaching format regardless of their own learning style preference. According to Taylor (1998) all instructors need to be able to address a variety of learning styles and Kay (1998) proposes that communication is improved by understanding how people learn. There is research to support varying teaching style to match learning style. Roach et al. (1993) examined alternative teaching styles in marketing classes. Filbeck and Smith (1996) looked at both teaching and learning styles along with age and gender. Borg and Shapiro (1996) studied teaching styles in economics classes. Hayes and Allinson (1996) analyzed 19 studies, which examined matching learning style to learning method and found support in 12 for improved learning performance.

Lindsay (1999) found that when learning style and teaching are congruent, there is an increase in student achievement and satisfaction. Dunn et al. (1995) discuss research showing higher grade point averages resulting from closer matches between teaching and learning styles. Wynd and Bozman (1996) found that older - non traditional students ( 24 or more years old) tended to be convergers, while traditional students (18-23 years old) were assimilators. They also found that students with higher GPA levels were convergers and assimilators, and those with lower GPA levels were accommodators and diverges.

Simpson and Du (2004) examined learning styles of distance students engaged in web-based courses and found that there was a significant relationship between learning style and students' enjoyment level, where convergers liked the courses the most and assimilators liked the course the least. They also found that there was a significant relationship between learning styles and students' participation and that divergers made the most "hits" and "reads", while assimilators made the least "posts." Ellis and Calvo (2006) suggest that in order for instructors to have production discussions with students on discussion forums that they must have meaningful interaction and thought provoking discussions. This requires that faculty be totally cognizant of the individual differences that enter into classroom discussions (Mujtaba and Preziosi, 2006).

Barnes et al. (2004) in a study examining online students and their learning styles found that $64 \%$ of the population surveyed was divergers, $32 \%$ were assimilators and $2 \%$ were either accommodators or convergers and $2 \%$ had a combination of all styles. Divergers choose cases as their first choice of course delivery methods and their second choice being on-line exams. Assimilators on the other hand, preferred on-line exams as their first choice of delivery methods followed by website navigation as their second choice. Chen et al. (2005) found that assimilator and accommodator outperformed divergers in web-based learning, while Wang et al. (2006) also examining webbased learning, found that divergers and assimilators outperformed accommodators and convergers, thus supporting Barnes et al. (2004) findings.

It is also important to recognize that teaching style often determines course delivery methods. According to Mumford (1995) many activities fail to achieve their potential because they concentrate only on one stage of the learning cycle. For example, lectures or books focus on delivering information while ignoring time to act practically on the information. Thus, we see that course delivery methods may impact course effectiveness as well as the differences in student learning styles and, therefore, educators are encouraged to consider other pedagogical approaches to enhance learning.

Educators may not be able to accommodate the learning styles of each student; however, they can design their courses and use a variety of teaching methods to ensure that learners benefit from a comfortable and rewarding experience. Many researchers have suggested that students should be encouraged to use all four learning styles instead of relying on one style. 
In addition to the usual lecture method, several other pedagogical vehicles can be considered to address the different learning styles.

Computer-based simulation exercises - Simulation exercises are available for several disciplines and have been used quite extensively as a tool to enhance the learning process. In essence, users learn by simulation. Exercises or games are developed to simulate real situations or scenarios and require users to use various skills, and knowledge and often require them to take risks and to experiment with things. The power of simulations is that they engage students more and students are more likely to learn from them as compared to the standard lecture (Andrade, 2007). Simulation, therefore, would be a desirable tool to use to stimulate the interest of accommodators. According to Kolb (1984) accommodators learn primarily from hands-on experience and intuition rather than from logical analysis.

Scenario planning - This method presents information that requires students to examine insights about the future and analyzing the probable impact of various factors on the future. Assimilators would be very receptive to scenario planning as they are very good planners and are focused on abstract ideas and concepts, and thus are good at creating models and defining problems.

Role play - role play is a very popular means of engaging students - here students are given specifics of a given situation and they are asked to assume roles and to make decisions relating to the information provided. This requires students to consider the concepts presented and then actively engage in discussions or activities to address the issues. This method would perhaps work well with convergers.

Projects - projects are widely used where individuals are encouraged to work either on a topic chosen by the instructor or one chosen by students where they are expected to generate a wide range of ideas and gather information. This process requires them to become creative and view situations from different perspectives. This vehicle would enhance the learning process of divergers.

Case Analysis - This is another popular tool used to develop analytical thinking. Students are required to use the information presented and to be able to put information into concise and logical form, which is consistent with case studies. A strength of assimilators is their propensity to define problems and this is quite relevant to the case study method.

Case in Point - This is a more progressive approach that uses the classroom and the student's experience as the case. It is more appropriate for qualitative courses than quantitative courses because of the focus on current behavior. Faculty who would use this with accomodaters should have considerable training in process observation and small group process, as well as training in the method itself. This method is being used at Harvard with much success (Parks, 2005).

\section{CONCLUSION}

Very few faculty members are fortunate enough to receive training on the teaching/learning process, including the whys and hows of instructional methodology. It is widely known that traditional faculty preparation continues to focus on areas of specialization and research methods. While these two focal points will always be essential, so is the development of knowledge and skill in classroom teaching.

The authors of this paper would certainly not be alone in stating this perspective. Ask anyone who has ever been a student about their college professors. They loved many of them. But, they would also give credence to the perspective that the authors of this paper provide.

Also, the value of presenting the Kolb Learning Model is a firm belief that an agenda must be set and acted upon. There may be other ways to call for reflection and action, but what better way than to focus on the learners (realizing that faculty also assumes the role learner from time to time). This is the reason for classrooms (traditional, on-line and labs) and an instructor who teaches, facilitates and guides student learning. The inclusion of descriptions for the most often used instructional methods was just icing on the cake. 


\section{AUTHOR INFORMATION}

Dr. Gooden is an Instructor in the College of Business at Florida International University and her research interest includes Transformational Leadership Practices, Foreign Direct Investment, Cultural Values, and Ground-Based vs. Electronic-based Instructional Delivery. Her work has been published in the International Business \& Economic Research Journal, Employee Responsibilities and Rights Journal and the New Horizons in Adult Education Journal as well as many conference proceedings. Dr. Gooden has also developed questionnaires which have been published in the 2002 Team and Organization Development Sourcebook, McGraw Hill and the Consultant's Big Book of Reproducible Surveys and Questionnaires.

She has been the recipient of two best paper awards: Paper entitled The relationship between Values Congruence and Innovation Capability at the Applied Business Research Conference held in Puerto Vallarta, Mexico, March 2002 and paper entitled Cultural Values and Leadership Behavior in the United States, Jamaica, and the Bahamas at The International Business and Economic Research Conference in Las Vegas, Nevada, October 2003.

Dr. Gooden is a member of the Academy of Management, Academy of International Business and the Strategic Management Society.

Robert C. Preziosi was named "Faculty Member of the Year in 2003". He is a professor of management with the Wayne Huizenga Graduate School of Business and Entrepreneurship at Nova Southeastern University. He is faculty chair of HRM and developed the school's Master's Degree in Leadership. He was the recipient of the school's first Excellence in Teaching Award. In December 2000 he was named Professor of the Decade

$\mathrm{He}$ is on the Editorial Boards of Employment Relations Today, Employee Responsibilities and Rights Journal, The Journal of Applied Management and Entrepreneurship, and The Journal of Business Case Studies.

He is listed in Who's Who in Finance and Industry, Who's Who in the World, and Who's Who in American Education. Four times he has been selected for Who's Who Among America's Teachers. In a recent book, North American Adult Educators, he was named 1 of 50 quintessential adult educators of the $21^{\text {st }}$ century.

He was the Editor of the Pfeiffer Annual on HRM and the Pfeiffer Annual on Management Development. Bob has just completed a book on leadership, The Leadership Road.

F. Barry Barnes is Professor and Chair of Leadership at the H. Wayne Huizenga School of Business and Entrepreneurship at Nova Southeastern University in Fort Lauderdale where he has taught since 1997. Dr.Barnes has a Ph.D. in Business from the University of Kansas and teaches graduate-level courses in leadership, strategic decision-making, and organizational behavior. He was selected as Faculty Member of the year in 1999 at the Huizenga School. His research interests are organization change and development, organizational learning, team development, and collective improvisation.

\section{REFERENCES}

1. Andrade, M. (2007). Advances in Learning: Classroom Simulations in The 2007 Pfeiffer Annual Human Resource Management, Preziosi, R.C. (editor). San Francisco, CA: Pfeiffer.

2. Barnes, F.B., Preziosi, R.C., and Gooden, D.J. (2004). An examination of the learning styles of online MBA students and their preferred course delivery methods. New Horizons in Adult Education 18 (3), 1630.

3. Barnes. F.B., Preziosi, R.C. and Alexakis,G. (2008). On-Campus Versus Off-Campus: A Comparative Analysis of MBA Learning Outcomes For a Classroom-Based Program, Journal of College Teaching and Learning, 5 (3), 25-32.

4. Borg, M. O. \& Shapiro, S. L. (1996). Personality type and student performance in principles of economics, The Journal of Economic Education, 27(1), 3-25.

5. Chen, C.J., Toh, S.C. \& Ismall, W.M. (2005). Are learning styles relevant to virtual reality? Journal of Research on Technology in Education, 38 (2) 123-141. 
6. Dunn, R. S., Griggs, A. J., Olson, Gorman, B. \& Beasley, M. (1995). A meta-analytic validation of the Dunn and Dunn learning styles model, Journal of Educational Research, 88(6), 353-61.

7. Ebeling, D. G. (2000). Adapting your teaching to any learning style, Phi Delta Kappan, 82(3), $247-248$.

8. Ellis, R.A. \& Calvo, R.A. (2006). Discontinuities in university student experiences of g-learning through discussion. British Journal of Educational Technology, 37 (1), 55-68.

9. $\quad$ Filbeck, G. \& Smith, L. L. (1996). Learning styles, teaching strategies, and predictors of success in corporate finance, Financial Practice and Education, 6(1), 74-85.

10. Hayes, J. \& Allinson, C. W. (1996). The implications of learning styles for training and development: A discussion of the matching hypothesis. British Journal of Management, 7(1), 63-73.

11. Honey, P. \& Mumford, A. (1986). The Manual of Learning Styles, Peter Honey, Maidenhead.

12. Kolb, D.A (1993). Learning Style Inventory. Boston, MA: McBer and Company,

13. Kolb, D. A. (1984). Experiential Learning: Experience as the Source of Learning and Development. Englewood Cliffs, NJ: Prentice-Hall.

14. Mujtaba, B. and Preziosi, R.C. (2006). Adult Education in Academia. Greenwich, Connecticut: Information Age Publishing.

15. Parks,S. D. (2005). Leadership Can Be Taught. Boston, MA: Harvard Business School Press.

16. Roach, S. S., Johnston, M. W. \& Hair, Jr., J. F. (1993, Fall). An exploratory examination of teaching styles currently employed in marketing education: Developing a typology and its implications for marketing students, Journal of Marketing Education, 32-38.

17. Simpson, C., and Du, Y. (2004). Effects of Learning Styles and participation on students' enjoyment level in distributed learning environments. Journal of Education for Library and Information Science 45(2) 123 136.

18. Taylor, J. (1998). Learning Styles: A practical tool for improved communications, Supervision, 59(7), 1819.

19. Tom, G., and Calvert, S. (1984). Learning style as a predicator of student performance and instructor evaluations. Journal of Marketing Education, 6(2) 14-17.

20. Tomlinson, J. (1996). Inclusive learning: The report of the learning difficulties and disabilities committee, FFEC, Coventry, England.

21. Wang, K.H., Wang, T.H., Wang, W.L. and Huang, S.C. (2006). Learning styles and format assessment strategy: enhancing student achievement in Web-based learning: Journal of Computer Assisted Learning, 22, 207-217.

22. Wynd, William and Bozman, Carl (1996). Student Learning Style: A segmentation strategy for higher education. Journal of Education for Business 71, 232-5 